\title{
Combined carbonate carbon isotopic and cellular ultrastructural studies of individual benthic foraminifera: 2. Toward an understanding of apparent disequilibrium in hydrocarbon seeps
}

\author{
Joan M. Bernhard, ${ }^{1}$ Jonathan B. Martin, ${ }^{2}$ and Anthony E. Rathburn ${ }^{3}$ \\ Received 15 January 2010; revised 14 July 2010; accepted 23 July 2010; published 22 October 2010.
}

[1] Numerous previous studies show disequilibrium between stable carbon isotope ratios of foraminiferal calcite and pore water dissolved inorganic carbon in hydrocarbon seeps, calling into question the utility of this widely used paleoceanographic tracer as a proxy. We use a recently developed method to compare stable carbon isotope ratios of foraminiferal carbonate with cell ultrastructural observations from individual benthic foraminifera from seep (under chemosynthetic bivalves) and nonseep habitats in Monterey Bay, California, to better understand control(s) of benthic foraminiferal carbon isotope ratios. Two attributes previously proposed to cause the isotopic offsets are diet and symbionts. Ultrastructural analysis shows that positive staining with Rose Bengal indicates presence of foraminiferal cytoplasm, bacterial biomass, or a combination of both and, thus, is not an unequivocal indicator of viability. We also show for the first time that some living seep foraminifera have endobionts. Results from our unique, yet limited, data set are consistent with suggestions that, in our sites, several foraminiferal species collected from seep clam beds may not survive there, diet and symbiont presence do not appear to be major contributors to disequilibrium, little calcification of seep-tolerant foraminiferal species occurs while seep conditions prevail, and microscale variability in habitats could influence $\delta^{13} \mathrm{C}$ of benthic foraminiferal carbonate. Results further suggest that our knowledge of benthic foraminiferal ecology and biomineralization, especially in extreme habitats such as seeps, must be bolstered before we fully understand the fidelity of paleoenvironmental records derived from benthic foraminiferal test $\delta^{13} \mathrm{C}$ data.

Citation: Bernhard, J. M., J. B. Martin, and A. E. Rathburn (2010), Combined carbonate carbon isotopic and cellular ultrastructural studies of individual benthic foraminifera: 2. Toward an understanding of apparent disequilibrium in hydrocarbon seeps, Paleoceanography, 25, PA4206, doi:10.1029/2010PA001930.

\section{Introduction}

[2] The geochemistry of benthic foraminiferal tests (shells) provides fundamental proxies for paleoceanographic studies. The assumption that the stable carbon isotope ratios of benthic foraminiferal carbonate $\left(\delta^{13} \mathrm{C}_{\text {test }}\right)$ correlate predictably with ambient $\delta^{13} \mathrm{C}$ values of dissolved inorganic carbon (DIC) $\left(\delta^{13} C_{\text {DIC }}\right)$ [e.g., McCorkle et al., 1990] has recently been drawn into question by observations that calcite of foraminiferal tests in cold methane seep habitats differ significantly from the ambient $\delta^{13} \mathrm{C}_{\mathrm{DIC}}$ of bulk pore water [Hill et al., 2003, 2004a, 2004b; Martin et al., 2004; Rathburn et al., 2003]. Such disequilibrium between ambient pore water and cooccurring foraminiferal calcite has important and

\footnotetext{
${ }^{1}$ Department of Geology and Geophysics, Woods Hole Oceanographic Institution, Woods Hole, Massachusetts, USA.

${ }^{2}$ Department of Geological Sciences, University of Florida, Gainesville, Florida, USA USA.

${ }^{3}$ Geology Program, Indiana State University, Terre Haute, Indiana,

Copyright 2010 by the American Geophysical Union. 0883-8305/10/2010PA001930
}

serious consequences for our understanding of past seep activities, which can significantly affect climate [e.g., Kennett, 2003; Leifer et al., 2006; Solomon et al., 2009]. Elucidating the cause of this disequilibrium will produce a more robust paleoenvironmental proxy. Until now, investigations involving foraminiferal biogenic carbonate isotopic signatures have focused on calibration [e.g., McCorkle et al., 2008; Rathburn et al., 2003] rather than on causation of this apparent disequilibrium because techniques were unavailable for assessing the biological cause of foraminiferal $\delta^{13} \mathrm{C}$ values.

[3] Importantly, in nonseep environments, foraminiferal $\delta^{13} \mathrm{C}_{\text {test }}$ values are not in equilibrium with DIC. The isotopic composition of ambient water DIC seems to have an influence, but there are inconsistencies such as "vital effect" disequilibrium and consistency of isotopic composition within a species [McCorkle et al., 1990]. In addition to vital effects that manifest as different isotopic signatures for different species living in the same pore waters (presumably with the same $\delta^{13} \mathrm{C}_{\mathrm{DIC}}$ value), specimens of the same species found living in different pore waters (i.e., with different $\delta^{13} \mathrm{C}_{\mathrm{DIC}}$ values) of the same core have the same isotope signal [McCorkle et al., 1997; Rathburn et al., 1996, 2003; 
among others]. This difference has led many authors [e.g., Gooday 2003; Hill et al., 2004a; Rathburn et al., 2003], to suggest that food may influence isotopic signatures in benthic foraminiferal carbonate. Similar conclusions were reached by Mackensen et al. [2006], who noted that Cibicidoides wuellerstorfi, living on methane seep worm tubes elevated well above the sediment water interface, have very negative carbon isotope signatures. They concluded that isotopically light material from the seep and ingested by the foraminifera had an influence on isotope ratios of their tests. Diet has also been suggested to influence the $\delta^{13} \mathrm{C}$ values of planktic foraminiferal carbonate [Uhle et al., 1997].

[4] Foraminifers in general ingest bacteria, fungi, algae, and small metazoans, plus take up dissolved organic carbon [reviewed in Lee and Anderson, 1991]. Although speciesspecific diets are unknown for nearly all deep-sea foraminifera, ultrastructural analyses indicate that some species ingest primarily phytodetrital remains [Heeger, 1990], while others are deposit feeders that likely rely primarily on bacteria [Goldstein and Corliss, 1994], and yet others are known to ingest metazoan tissue [Linke et al., 1995]. Preliminary observations suggest individuals of any given foraminiferal species have similar food vacuole contents if the specimens were collected in the same environment [e.g., Goldstein and Corliss, 1994], but preliminary examination suggests that foraminiferal conspecifics collected from different environments have variation in their diets (J. M. Bernhard, unpublished data, 1997; S. T. Goldstein, personal communication, 2003). Although the mechanism is unknown for foraminifera, differences in dietary composition is known to affect carbon isotope values of bones and other metazoan tissues [e.g., Lee-Thorp, 2008; Levin and Michener, 2002]. The dietary habits of foraminifera living in methane seeps have never been described, and thus, it is unknown if diet causes or contributes to the large disequilibrium observed in these environments.

[5] From a somewhat different perspective, the presence of photosynthetic symbionts is known to influence the isotopic signatures of planktonic foraminiferal calcite [e.g., Spero, 1998], corals, and shallow water benthic foraminifera [e.g., Erez, 1978]. Similarly, an endobiont-bearing sulfidetolerant foraminiferal species has a light carbonate $\delta^{13} \mathrm{C}$ value (Virgulinella fragilis, -6.4\%o [Bernhard, 2003]) compared to most foraminifera, and thus, the presence or absence of heterotrophic and/or chemoautotrophic symbionts in benthic foraminiferal conspecifics may help explain isotopic variability within the carbonate of seep foraminiferal assemblages. Heterotrophic and/or chemoautotrophic bacterial symbionts may affect carbon cycling within the microhabitat of the foraminiferal test and cytoplasm by fractionating DIC in microenvironments within and surrounding the foraminifer to lighter values than in bulk pore water. Isotopically light DIC in microenvironments should cause the foraminiferal tests to be isotopically lighter than tests of conspecifics living outside seeps: a trend not previously observed [e.g., Rathburn et al., 2003]. Endosymbionts, however, have not yet been found in foraminifera living in seep habitats, and ectosymbionts have only been described from one individual seep foraminifer, on the basis of limited ultrastructural data [Bernhard et al., 2001].
[6] Other possible explanations for disequilibrium of isotope composition of benthic foraminifera have been postulated. Stott et al. [2002] proposed that foraminifera calcify at the sediment water interface or a particular sediment horizon, thereby incorporating only the DIC from bottom waters or the horizon's pore waters; subsequent migration into anoxic zones characterized by extremely low $\delta^{13} \mathrm{C}$ values hypothetically results in an apparent disequilibrium between ambient conditions and tests. However, previous studies that examined Rose Bengal-stained foraminifera within seep sediments found distinct vertical distribution patterns and no evidence that species-specific depth distributions change over time [e.g., Rathburn et al., 2003]. Torres et al. [2003] suggested that isotopic disequilibrium of foraminifera at Hydrate Ridge seeps (Oregon USA margin) resulted from calcification only during times of little methane venting or when there was intermittent seawater flow into the sediments. Variations in flow rate and direction have been documented at the Hydrate Ridge seeps. These variations, which occur at frequencies of a few days' duration and perhaps as rapidly as tidally [e.g., Tryon et al., 1999, 2002], were linked to gas hydrate dissociation and gas-driven fluid flow. Downward flow into sediments linked to gas hydrate dissociation has also been measured in the Gulf of Mexico [Solomon et al., 2008]. Variations in the isotopic composition of pore water at frequencies matching flowmeter results of Tryon et al. [1999, 2002] have not been published to our knowledge. Further, daily or tidal periodicities in calcification have not been documented in deep-sea benthic foraminifera.

[7] We hypothesize that the carbon isotopic composition of foraminiferal carbonate is influenced by diet and/or microscale pore water variability caused by nonphotosynthetic (i.e., heterotrophic or chemoautotrophic) bacterial or archaeal symbionts. Alternatively, we hypothesize the perceived disequilibrium results from inaccurate viability assessments where foraminifera thought to be living in seeps actually represent dead specimens, for which tests more closely reflect nonseep $\delta^{13} \mathrm{C}_{\mathrm{DIC}}$ values. To address these hypotheses, we developed a method that coupled isotopic and ultrastructural analyses [Martin et al., 2010] and use this novel approach here to compare the carbonate stable isotope value of individual foraminifers' carbonate tests with their cytology.

\section{Methods}

[8] Specimens were collected from the Clam Flats seep and an adjacent nonseep area in Monterey Bay, California $\left(36^{\circ} 44.7^{\prime} \mathrm{N} 122^{\circ} 16.6^{\prime} \mathrm{W} ; \sim 1003 \mathrm{~m}\right.$ water depth). Neither gas hydrates nor bottom-simulating reflectors that would indicate their presence have been reported from the sampling region. Although flow rates have not been measured at the Monterey Bay seeps, repeated sample collection over approximately 6 months show that sulfate and alkalinity concentrations changed little over that period and reflect relative stability of flow from these seeps [Martin et al., 1997]. At the time of our sampling, a reconnaissance of the area resulted in selection of three large beds of live vesicomyid clams representing sites of active methane and sulfide seepage [e.g., Barry et al., 1996]. A suite of samples was obtained from each designated site; 
this contribution describes analyses from a subset of our collections.

[9] Sediments were obtained using pushcores $(8.1 \mathrm{~cm}$ inner diameter) with the remotely operated vehicle Jason. When sampling clam beds, care was taken to target vertically oriented bivalves so that the pushcore wall would not jostle the clam significantly during coring, thus allowing collection of undisturbed sediments. Cores were sent to the sea surface via a flotation elevator to minimize the period through the thermocline and recovery onto the surface support vessel. After the elevator was secured on deck, the pushcores were taken into an environmental room approximating in situ temperature $\left(\sim 5^{\circ} \mathrm{C}\right)$. Within an hour, the surface $1 \mathrm{~cm}$ of each core was sliced from the underlying sediments. Some samples were used for pore water extractions, and some were preserved for foraminiferal analyses. Pore water extracted for isotope samples were compromised during transport, and we thus lack $\delta^{13} \mathrm{C}_{\mathrm{DIC}}$ values for these pore waters. For this paper, we use previously measured values from these seeps to infer the presence of disequilibrium between the foraminiferal carbonate and DIC [Martin et al., 1997, 2004]. Samples for foraminifera for this study were placed in a high-density polyethylene (HDPE) container, fixed in 3\% glutaraldehyde buffered with $0.1 \mathrm{M} \mathrm{Na}$ cacodylate acid (pH 7.2 [e.g., Bernhard et al., 2000]), and kept $\sim 5^{\circ} \mathrm{C}$ during transport and until processing. To aid in identifying cytoplasm-containing specimens, a saturated solution of Rose Bengal was added to the fixative solution approximately one week prior to specimen isolation from sediments. The employed methodology is described in detail by Martin et al. [2010]. In brief, because of requirements for standard transmission electron microscope (TEM) preparation, and isotopic analyses, our standard methods required modification.

[10] Because of resource limitations, not all specimens that produced reliable $\delta^{13} \mathrm{C}$ values [Martin et al., 2010] were analyzed for cell structure. Specimens were prioritized within each common calcareous species (Bulimina mexicana, Buliminella tenuata, Chilostomella oolina, Cibicidoides wuellerstorfi, Globobulimina pacifica, Uvigerina peregrina); highest priority was given to those species where data were recovered from both seep and nonseep Rose Bengal-stained specimens as well as to conspecifics exhibiting maximum differences in isotopic signature for either habitat. After stable isotope analysis, selected specimens $(\mathrm{n}=34)$ were prepared for TEM as described by Martin et al. [2010]. Specimens were sectioned into $250 \mathrm{~nm}$ "thick" and $90 \mathrm{~nm}$ "thin" sections. Thick sections were air-dried on microscope slides, stained with $1 \%$ toluidine blue $\mathrm{O}$, examined, and photographed with a Zeiss Axiovert 40C tissue culture microscope to visualize gross cell structure. Per standard practice to enhance membrane visualization, thin sections were poststained with a saturated uranyl acetate solution in 50\% ethanol and a modified version of Sato's lead citrate [Hanaichi et al., 1986] and examined with either a Zeiss 902A or a Zeiss 10CA TEM. All 34 specimens were examined for (1) food vacuole contents such as inorganic detritus and bacterial, algal, and/or metazoan remains [Goldstein and Corliss, 1994; Heeger, 1990]; (2) symbiont presence/absence [e.g., Bernhard, 2003; Bernhard et al., 2006]; and (3) intact organelles (i.e., nuclei, Golgi bodies, peroxisomes, mitochondria, endoplasmic reticulum, vacuoles). For this study, a specimen was considered dead if intact organelles were absent or deemed living if at least three types of intact organelles were found. If only one or two organelle types were identifiable, the specimen was deemed to be recently dead or dying. Pore plugs (thickened membranes occurring in test pores) and bacteria entrained in externally associated inorganic debris were potentially present in both live and dead specimens, so their presence had no bearing on viability assessments.

\section{Results}

\subsection{Rose Bengal Staining and Gross Cell Structure}

[11] All analyzed specimens stained with Rose Bengal, although the staining intensity and pattern varied (Figures 1a$1 \mathrm{~d}$ and insets), often being restricted to the final (youngest) one or two chambers. The opacity of tests in conspecifics of some species (e.g., C. wuellerstorfi, U. peregrina) varied; when the tests of some individuals that appeared to have less intense staining were fractured, bright cytoplasmic staining was observed (Figure 1d).

[12] Gross morphological attributes apparent in thick sections of epoxy-embedded specimens also differed substantially among individuals. Some foraminifera had abundant obvious vacuoles (Figure 1e) while others lacked welldeveloped vacuolization (Figure 1f). In a few cases, masses of inorganic material exceeded organic material (Figure 1g).

\subsection{Ultrastructural Observations}

[13] Although the direct transfer from phosphate buffered saline (PBS) to $70 \%$ ethanol in our procedure [Martin et al., 2010] produces more darkly stained material than our standard procedure [Bernhard et al., 2000], identifiable organelles were apparent in many specimens (Figures $1 \mathrm{~h}-1 \mathrm{n}$ and Table 1). Cristae (membrane invaginations) of mitochondria were often difficult to discern both in nonseep and seep specimens, although the double membrane of mitochondria could be discerned if viewed at the appropriate angle (Figure 1k). Lipid was also prevalent; sometimes the proloculus appeared to be almost completely full of lipid (Figure 11). Changes in cytoplasmic composition from chamber to chamber were common. As noted in thick section light micrographs (e.g., Figure 1e), the cytoplasm of terminal (i.e., youngest) and, often, penultimate chambers was typically diffuse, imparting a "frothy" or "ropey" appearance (Figure S1a) that generally included foreign material as well as mitochondria and peroxisomes (Figure S1b). ${ }^{1}$ These changes in cytoplasmic texture across chambers likely represent known differences between pseudopodial and cell body cytoplasm [Alexander and Banner, 1984].

[14] Degraded organelles were common. The most frequent and obviously compromised organelles were vacuoles where membranes were ruptured. Such ruptured vacuoles occurred in specimens both with and without other wellpreserved organelles (i.e., living, dead, and dying specimens).

\footnotetext{
${ }^{1}$ Auxiliary materials are available in the HTML. doi:10.1029/ 2010PA001930.
} 

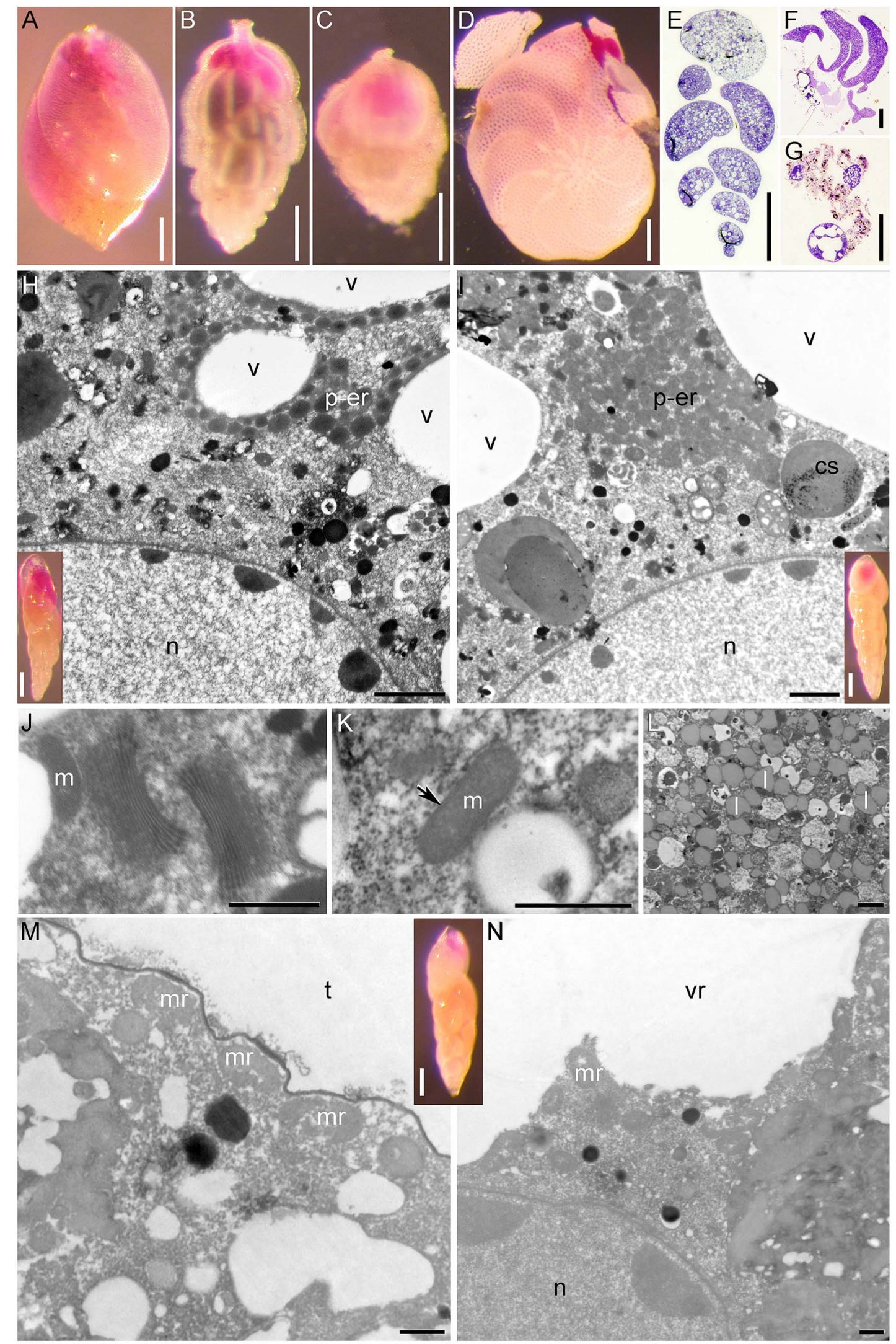

Figure 1 
Table 1. Characteristics of Foraminifera Analyzed for Stable Carbon Isotopes and Cell Ultrastructure ${ }^{\mathrm{a}}$

\begin{tabular}{|c|c|c|c|c|c|c|}
\hline Species & Specimen & Core & $\delta^{13} \mathrm{C}$ (Error) & Food Type & Bacteria? & Organelles \\
\hline B.mexicana & 85 & 8 & $1.4(0.85)$ & diatoms, detritus & none & ER, M, G \\
\hline B.mexicana & 83 & 8 & $3.2(0.85)$ & detritus & none & NA \\
\hline B.mexicana & 36 & 21 & $-1.6(0.85)$ & detritus & Parasites & $M$ \\
\hline B.mexicana & 51 & 21 & $-0.7(0.85)$ & NA & Parasites & $N A$ \\
\hline B.mexicana & 52 & 21 & $0.9(0.85)$ & algae, detritus & Parasites & $M^{*}, V^{*}$ \\
\hline B.tenuata & 128 & 8 & $0.6(0.85)$ & plastids & Endobionts & $\mathbf{N}, \mathbf{P}, \mathbf{E R}, \mathbf{M}, \mathbf{V}$ \\
\hline B.tenuata & 130 & 8 & $0.9(0.85)$ & unidentifiable & Endobionts & $\mathrm{V}, \mathbf{P}, \mathbf{E R}, \mathrm{M}, \mathrm{G}$ \\
\hline B.tenuata & 127 & 8 & $-1.0(0.85)$ & detritus, unidentifiable & none & $\mathbf{M}, \mathbf{P}, \mathbf{E R}, \mathrm{V}, \mathbf{G}$ \\
\hline B.tenuata & 129 & 8 & $0.9(0.85)$ & detritus & Endobionts & V, P, ER, M \\
\hline B.tenuata & 102 & 41 & $-3.2(0.85)$ & plastids & Endobionts & $V, P, E R, M$ \\
\hline B.tenuata & 103 & 41 & $-2.1(0.85)$ & plastids & Endobionts & $V, P, N, G$ \\
\hline B.tenuata & 104 & 41 & $-2.0(0.85)$ & $N A$ & none & $V, M^{*}$ \\
\hline B.tenuata & 105 & 41 & $-1.3(0.85)$ & $N A$ & none & $N A$ \\
\hline C. ovoidea & 71 & 8 & $-0.4(0.85)$ & algae, detritus & none & $\mathbf{V}, \mathbf{P}, \mathbf{M}$ \\
\hline C. ovoidea & 109 & 41 & $-3.2(0.85)$ & unidentifiable & none & $N A$ \\
\hline C.wuellerstorfi & 125 & 8 & $-0.2(0.06)$ & unidentifiable & Parasites & (L) \\
\hline C.wuellerstorfi & 33 & 21 & $0.6(0.31)$ & algae, diatoms, detritus & Parasites & $M ?, V^{*}$ \\
\hline C.wuellerstorfi & 40 & 21 & $-3.0(0.06)$ & diatoms, detritus & Parasites & $(L)$ \\
\hline C.wuellerstorfi & 58 & 21 & $0.0(0.06)$ & diatoms, muscle & none & $N^{*}, M ?^{*}$ \\
\hline C.wuellerstorfi & 60 & 21 & $-0.4(0.06)$ & diatoms, detritus & none & $N^{*}, M ?^{*}, P^{*}$ \\
\hline C.wuellerstorfi & 62 & 21 & $2.1(0.85)$ & diatoms, detritus, bacteria & Parasites & $P, M ? *$ \\
\hline G. pacifica & 75 & 8 & $1.1(0.85)$ & diatoms, detritus & none & $\mathrm{V}, \mathbf{P}, \mathbf{E R}, \mathbf{M}$ \\
\hline G. pacifica & 48 & 21 & $-2.0(0.31)$ & $N A$ & none & $N A$ \\
\hline G. pacifica & 49 & 21 & $1.1(0.85)$ & $N A$ & none & $N A$ \\
\hline G. pacifica & 97 & 41 & $-7.9(0.31)$ & diatoms, detritus & none & $V^{*}, P^{*}, M^{*}$ \\
\hline G. pacifica & 98 & 41 & $-8.5(0.05)$ & diatoms, detritus & none & $P, E R$ \\
\hline G. pacifica & 99 & 41 & $-6.0(0.85)$ & algae, detritus, muscle & none & $V, P, E R, M$ \\
\hline G. pacifica & 113 & 41 & $-5.7(0.06)$ & detritus, bacteria & Endobionts, Parasites? & $V, P, E R, M ?$ \\
\hline G. pacifica & 114 & 41 & $-5.5(0.31)$ & algae & none & $P, E R, M^{*}$ \\
\hline U. peregrina & 76 & 8 & $-0.6(0.85)$ & algae, detritus & none & $\mathbf{V}, \mathbf{P}, \mathbf{E R}, \mathbf{M}, \mathbf{G}$ \\
\hline$U$. peregrina & 77 & 8 & $0.9(0.85)$ & detritus & none & $\mathrm{P}, \mathrm{V}^{*}$ \\
\hline U. peregrina & 44 & 21 & $-2.2(0.85)$ & unidentifiable & none & $N A$ \\
\hline$U$. peregrina & 100 & 41 & $-0.5(0.31)$ & algae, detritus & none & $M, G$ \\
\hline U. peregrina & 112 & 41 & $-0.7(0.085)$ & diatoms & none & $N A$ \\
\hline
\end{tabular}

${ }^{a}$ Italics equates to seep specimen, regular font equates to nonseep specimen, bold equates to live ( $\geq 3$ organelle types). Specimen refers to specimen number. ER, endoplasmic reticulum; M, mitochondria; G, Golgi; V, vacuoles; P, peroxisomes; N, nucleus; L, lipid (not considered an organelle, only listed if present in absence of other organelles); NA, not applicable. Asterisk equates to ruptured or degraded; ? equates to indeterminate.

In some specimens, however, cell membranes and vacuole membranes were consistently disrupted (Figures $1 \mathrm{~m}$ and $1 \mathrm{n}$ ), as were mitochondria (Figure $1 \mathrm{~m}$ ). Nearly two thirds (22 of 34) of the foraminifera exhibited multiple organelle types in a state of degradation and were thus considered dead or dying.

[15] All species had copious ingested material except for B. tenuata, which typically lacked identifiable food vacuoles. Ingested material in species other than B. tenuata included inorganic detritus, diatom frustules, chloroplasts, bacteria, and unidentifiable material (Figures 2 and S1c). In some cases, plastids appeared sequestered rather than being digested (Figure 1h), as has been observed in other deep-sea benthic foraminifera [Bernhard and Bowser, 1999]. Half of the live $B$. tenuata and one of the live $G$. pacifica had plentiful intracellular bacteria unassociated with food vacuoles. Occasionally, a bacterium was transitioning across a vacuole

Figure 1. Photomicrographs of analyzed foraminifera. Rose Bengal-stained specimens viewed with reflected light: (a) Globobulimina pacifica (seep, specimen 97, -7.9\%; dying), (b) Uvigerina peregrina (nonseep, specimen 76, -0.6\%o, live), (c) Uvigerina peregrina (nonseep, specimen 77, 0.9\%, dead), (d) Cibicidoides wuellerstorfi (nonseep, specimen $125,-0.2 \%$, dead). Toluidine blue-stained thick sections viewed with transmitted light: (e) Uvigerina peregrina (specimen 76), (f) Cibicidoides wuellerstorfi (specimen 125), (g) Uvigerina peregrina (specimen 77). Transmission electron micrographs: (h) Buliminella tenuata (nonseep, specimen 128, 0.6\%o, live) and (i) Buliminella tenuata (seep, specimen 103, $-2.1 \%$, live). Note the similarity between Figures $1 \mathrm{~h}$ and $1 \mathrm{i}$ showing nuclei (n), vacuoles (v), peroxisomes-endoplasmic reticulum complexes (p-er), and sequestered chloroplast (cs). (j) Paired Golgi bodies and mitochondria (m) in seep B. tenuata (specimen 103). (k) Mitochondria (m) showing double membrane (arrow) in live nonseep U. peregrina (specimen 76). (1) Proloculus with copious lipid (1) in dead seep C. wuellerstorfi (specimen 58; 0\%). (m, n) Seep B. tenuata (specimen $105,-1.3 \%$, dead). Ruptured mitochondria (mr) and location of test (t) (prior to decalcification) (Figure 1m). Ruptured vacuoles (vr), also note nucleus (n) (Figure 1n). Reflected light image of Rose Bengal-stained specimen shown in corresponding TEM image panel are shown in insets. Scale bars are $100 \mu \mathrm{m}$ for Figures $1 \mathrm{a}-1 \mathrm{~g}, 2 \mu \mathrm{m}$ for Figures $1 \mathrm{~h}-1 \mathrm{i}$ and Figure 11, $500 \mathrm{~nm}$ for Figures $1 \mathrm{j}-1 \mathrm{k}$ and Figure $1 \mathrm{~m}-1 \mathrm{n}$, and $100 \mu \mathrm{m}$ for insets. 

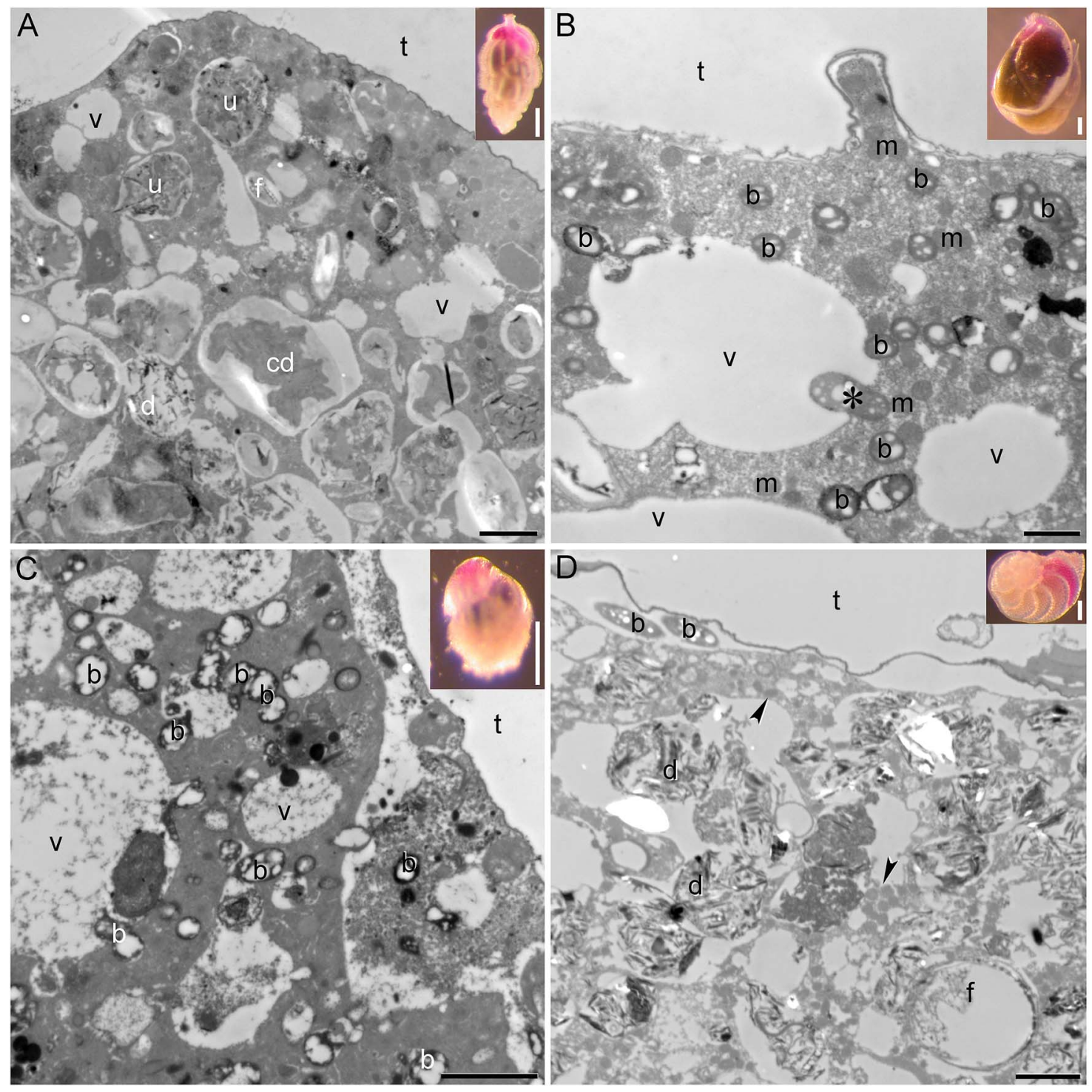

Figure 2. Transmission electron micrographs of foraminiferal cytoplasm at cell peripheries. (a) Example of food vacuoles in $U$. peregrina (specimen $76,-0.6 \%$ ) showing $\mathrm{u}$, unidentified material; cd, chloroplast undergoing digestion; $d$, inorganic debris; $f$, portion of diatom frustule. (b) Bacterial (labeled b) endobionts in live seep G. pacifica (specimen 113, -5.7\%o). Asterisk is bacterium transitioning from vacuole into foraminiferal cytoplasm. (c) Bacteria in decaying seep foraminiferal cytoplasm (B. mexicana, specimen $36,-1.6 \%$, dead). Note area of bacteria approaches that of foraminiferal cytoplasm. (d) Intact bacteria and highly degraded cytoplasm in seep C. wuellerstorfi (specimen 33, 0.6\%o, dead). Arrowheads are remnant organelles (perhaps peroxisomes). Reflected light image of Rose Bengal-stained specimen shown in corresponding TEM image panel are shown in insets. Key same as Figure 1. Scale bars are $2 \mu \mathrm{m}$ for Figures $2 \mathrm{a}, 2 \mathrm{c}$, and 2d; $1 \mu \mathrm{m}$ for Figure $2 \mathrm{~b}$; and $100 \mu \mathrm{m}$ for insets.

membrane, suggesting active ingestion but not digestion by the foraminifer. In one TEM micrograph, bacteria of a single morphotype occurred in a large vacuole, in the transition across the vacuole membrane, and also intimately incorporated in the cytoplasm (Figure $2 b$ ). Some regions of certain foraminifera had approximately equal surface areas of bacteria and foraminiferal cytoplasm (Figure 2c).

[16] The cytology of the observed C. wuellerstorfi $(\mathrm{n}=10)$ differs from that of the five other species examined ultra- structurally (e.g., Figures 11 and 2d). Sections of C. wuellerstorfi were electron dense, making it challenging to identify most organelles. The nucleus in each of two C. wuellerstorfi was obviously degraded (Figure S1d). The structures most similar to mitochondria in C. wuellerstorfi were much smaller than in other species (not shown). In all cases, the proloculus and initial few chambers of $C$. wuellerstorfi were composed almost exclusively of lipids (Figure 11). Bacteria were often observed in C. wuellerstorfi (Figure 2d). 

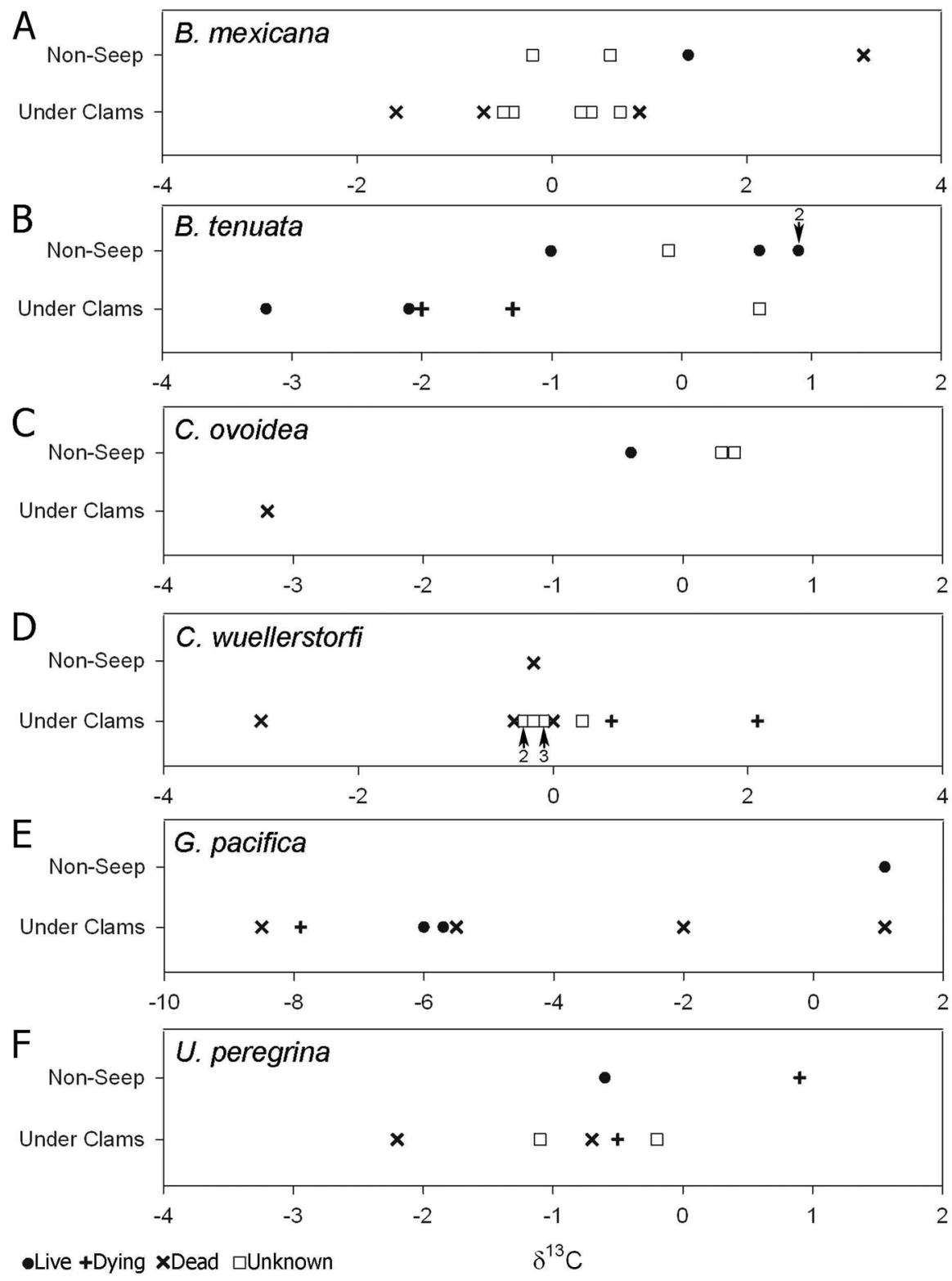

Figure 3. (a-f) Plots of foraminiferal test $\delta^{13} \mathrm{C}$ presented by species and habitat (nonseep and seep). Data are presented for the specimens analyzed for both stable carbon isotopes and cell ultrastructure (live (solid circles), dying/recently dead (plus), dead (crosses)) as well as those that produced reliable $\delta^{13} \mathrm{C}_{\text {test }}$ but were not analyzed with TEM (open squares). Note differences in $x$ axes scales. The numerals under or over a symbol, when present, represent the number of individuals with that isotope value.

No C. wuellerstorfi from either habitat were living at the time of collection. Bacteria were abundant on the external surface of pore plugs of three seep C. wuellerstorfi (Figures S1e-S1f).

\subsection{Isotope Signatures Regardless of Viability}

[17] In four of the six species, more seep specimens than nonseep specimens were isotopically analyzed. The exceptions were $B$. tenuata, where five specimens were analyzed from each habitat, and $C$. oolina, where more nonseep specimens $(n=3)$ were analyzed than seep specimens $(n=1)$. The reasons for such analytical unevenness is that species' densities vary between habitats (e.g., deep infaunal $G$. pacifica versus epifaunal C. wuellerstorfi [Corliss, 1991]) and because some isotopically analyzed specimens lacked sufficient test mass to produce reliable $\delta^{13} \mathrm{C}$ data.

[18] Regardless of a specimen's viability, in general, the $\delta^{13} \mathrm{C}$ values of nonseep conspecifics were less depleted than those of conspecifics collected under seep clams (Table 1 and Figure 3). When considering all species together, seep specimens were significantly lighter isotopically than nonseep specimens ( $\mathrm{n}=54$; Mann-Whitney $\mathrm{U}$ test, $\alpha<0.01)$. In general, the most negative carbon isotope ratios of any given 
conspecific collected from under seep clams came from dead specimens, as was the case in five of our six most common species (Figure 3 ). When considering all specimens, both live and dead, the range in $\delta^{13} \mathrm{C}$ in nonseep specimens was $4.7 \%$ o $\left(-1.5 \%-3.2 \%\right.$ ), while the range in $\delta^{13} \mathrm{C}$ of seep specimens was more than twice as large $\left(10.6 \%\right.$; $-8.5 \% 0^{-}$ $2.1 \%$ [Martin et al., 2010]). Additionally, the range in $\delta^{13} \mathrm{C}$ within a given species from a single sample was often considerable (Figures 3a, 3b, 3d). For example, C. wuellerstorfi from a seep core ranged from $-3.0 \%$ to $2.1 \%$ o $(\mathrm{n}=12)$, and $B$. tenuata from a seep core ranged from $-3.2 \%$ to $0.6 \%$ $(\mathrm{n}=5)$. While seep $G$. pacifica exhibited the largest isotopic range of all species $(9.6 \%, n=7)$, specimens were analyzed from two cores, each obtained from a different clam bed. The isotopic range in G. pacifica within each core was $~ 3 \%$. $(-8.5 \%$ to $-5.5 \%$ in core 41 and $-2.0 \% 0-1.1 \%$ in core 21$)$.

\subsection{Ultrastructural $\delta^{13} \mathrm{C}$ Comparison}

[19] When viability and isotope data are considered together, the $\delta^{13} \mathrm{C}_{\text {test }}$ values are lighter in live seep specimens compared to their live nonseep conspecifics in the two species that had live specimens from each habitat (B. tenuata and G. pacifica). These differences are not statistically significant (Mann-Whitney U test). Indeed, there are no significant differences in the isotope signatures of live versus dead conspecifics (regardless of habitat), nor of conspecifics with bacterial associates (endobionts, ectobionts, and/or parasites; see section 4) versus those without bacterial associates. No statistical difference existed in $\delta^{13} \mathrm{C}_{\text {test }}$ values between detritivores and those with other diets (e.g., algae). Lack of significance likely could be due to small sample sizes and points to the need for additional linked ultrastructural isotope analyses to measure $\delta^{13} \mathrm{C}$ values of foraminiferal tests that were unequivocally live at the time of collection.

\section{Discussion}

[20] A range of health was observed across specimens from both habitats, as evidenced by foraminiferal cytoplasmic preservation. Importantly, some seep specimens were living at the time of fixation and some nonseep specimens were dead at the time of fixation. Rose Bengal-stained specimens were not necessarily live foraminifera, confirming previous assertions of Bernhard [1988] and Sen Gupta et al. [1997]. In our study, TEM revealed that Rose Bengalstained foraminiferans $(\mathrm{n}=34)$ were either live $(35 \%)$, obviously dead (44\%), or recently dead/dying (21\%). Of the six species analyzed, only one (C. wuellerstorfi) lacked living specimens in both habitats.

[21] Cibicidoides wuellerstorfi is an epibenthic species that typically attaches to substrates above the sediment water interface in nonseep habitats [Lutze and Thiel, 1989] as well as in seep habitats [e.g., Lobegeier and Sen Gupta, 2008; Mackensen et al., 2006; Sen Gupta et al., 2007]. Remnant clam shells and elevated carbonate rocks likely provide substrate for $C$. wuellerstorf $i$ in the Clam Flats area, perhaps resulting in higher densities compared to surrounding nonseep habitats (A. E. Rathburn et al., unpublished data, 2007). Although Rose Bengal-stained C. wuellerstorfi were present in sediments under seep clams in our study, ultrastructural analysis shows all specimens were dead. Thus, data including Rose Bengal-stained C. wuellerstorfi from seep sediments [e.g., Lobegeier and Sen Gupta, 2008] should be cautiously interpreted. Possibly, Rose Bengalstaining represents remnant cytoplasm in a specimen that died because of seep exposure or a foreign organism living in a foraminiferal test (e.g., "squatters") [Grimm et al., 2007; Moodley, 1990]. Regardless, TEM results indicate lack of identifiable living eukaryotic cytoplasm in any of the examined C. wuellerstorfi.

[22] With one exception (Buliminella tenuata), all the observed common foraminiferal species from both habitats appeared to be deposit feeders, as previously observed for some deep-sea foraminifera [Goldstein and Corliss, 1994]. Most species also had remains of diatom frustules, but of course, with our data it is not possible to know if empty frustules were ingested during deposit feeding or if diatom cytoplasm was contained in frustules at the time of ingestion. Buliminella tenuata from both habitats rarely had full food vacuoles but sometimes had ingested and/or sequestered chloroplasts. Chloroplast sequestration is a specialized type of putative symbiosis observed in certain marine fauna, including foraminifera [e.g., Cedhagen, 1991; Leutenegger and Hansen, 1979; Leutenegger, 1984]. Often such plastidharboring foraminifera inhabit sulfidic environments [e.g., Bernhard and Alve, 1996; Bernhard and Bowser, 1999; Bernhard, 2003], implying that the sequestered chloroplasts may play a critical role for survival in these habitats [Grzymski et al., 2002]. In sum, because the diets of specimens we examined were similar for conspecifics of both seep and nonseep specimens while the $\delta^{13} \mathrm{C}$ values differed somewhat (Figure 3), our limited data do not show an obvious relationship between diet and carbonate isotopic value in seeps. However, our data are not conclusive at this time; food cannot be excluded as an influence on foraminiferal carbonate isotopic composition. Additional data are needed from conspecifics with a more varied diet.

[23] Further, a clear trend between isotope composition and bacterial presence/absence was not noted, primarily due to the fact that endobionts were found in some of our nonseep specimens. Thus, our data do not support the hypothesis that symbionts significantly affect the $\delta^{13} \mathrm{C}_{\text {test. }}$. Single-chamber analysis, manipulative experiments, and/or finer resolution measurements of the $\delta^{13} \mathrm{C}_{\mathrm{DIC}}$ are required before this possibility is fully resolved (also see below). While the association of benthic foraminifera with heterotrophic or chemoautotrophic bacteria as symbionts is not uncommon in other sulfidic habitats, they are rare in foraminifera from nonsulfidic habitats [Bernhard et al., 2010; Goldstein and Corliss, 1994; Richardson and Rutzler, 1999]. Interestingly, bacterial associations across the examined population exhibited a continuum, from prey in food vacuoles, to endobionts, to what could be considered parasites, to predators or scavengers. The presence of ectobionts on $C$. wuellerstorfi pores in combination with bacterial predators or parasites could be considered a unique type of microbial consortia, where different bacteria and/or archaea live in close association. A dead foraminiferal cell can alter organic carbon content from ambient sediment values of $\sim 1 \%-4 \%$ [Bernhard, 1992] to 
nearly $100 \%$ within its test. The tests of dead and recently dead foraminifera provide organics and well-defined spaces within which geochemical gradients will form, to be available to various microbiota. Such microbial activity could affect isotope composition on a fine scale.

[24] Because the range in $\delta^{13} \mathrm{C}_{\text {test }}$ values for this study's Rose Bengal-stained specimens was generally comparable to those of similarly stained foraminifera from other seep studies [e.g., Martin et al., 2004; Rathburn et al., 2003], our study also suggests that the carbon isotope ratio in seep foraminiferal carbonate is in disequilibrium from that in seep pore waters. Our results en toto suggest, however, that there may be another mechanism to account for disequilibrium in addition to the possibilities that foraminifera calcify at a certain depth horizon and then migrate [Stott et al., 2002] or that foraminifera calcify in seeps only when flow stagnates or reverses direction [Torres et al., 2003].

[25] Current data are congruent with a new hypothesis for isotopic disequilibrium: some benthic foraminiferal species inhabit seeps, but most benthic foraminiferal species do not inhabit seeps, thus their tests more closely reflect nonseep $\delta^{13} \mathrm{C}_{\mathrm{DIC}}$. In this explanation, which requires rigorous testing, foraminiferans are introduced to seeps via resuspension (reviewed by Alve [1999]), even at $>1400 \mathrm{~m}$ water depth [Kitazato, 1995]. Such transportation is supported because foraminiferal diversity in seep samples is roughly comparable to that of nonseep samples, at least for some sites [Robinson et al., 2004] and because seeps lack endemic foraminiferal species. Further, specifically regarding seeps with bivalves, foraminifera could be living adjacent to the clam but be in a nonseep habitat and then be transported into inhospitable seep conditions by the activity of the clam foot. Finally, although less likely, seeps have been proposed to migrate, although the migration rate appears to be on the scale of decades to centuries [e.g., Hornbach et al., 2007; Naehr et al., 2000]. The migration and formation of seeps would trap live foraminifera in the chemically different and potentially toxic pore water. The edges of seeps may migrate more rapidly than the whole scale movement of seeps, also causing a nonseep habitat to become a seep habitat within a foraminiferan's life span.

[26] In this scenario and regardless of the mechanism for foraminiferal exposure to seeps, most foraminifera would die during exposure to seep conditions, probably due to either bacterial invasion (Figures $2 \mathrm{~b}-2 \mathrm{~d}$ ) or environmental toxicity. Subsequent bacterial growth within decaying cytoplasm would result in a positive reaction with Rose Bengal until all organics are consumed, whence the empty test would not stain with Rose Bengal. Other work indicates that a positive reaction with Rose Bengal can occur in foraminifera for months to years after death in nonseep habitats [Bernhard, 1988; Corliss and Emerson, 1990]. If any authigenic carbonate overgrowths precipitate (on live or dead specimens) during seepage, their isotopic ratios would cause $\delta^{13} \mathrm{C}$ to tend toward seep values because of the pore water $\delta^{13} \mathrm{C}_{\text {DIC }}$ and bacterial consortium activities. Regardless of the potential for authigenic overgrowths with isotopically light isotope ratios, the bulk isotopic compositions of most tests of Rose Bengal-stained seep foraminifera do not equal isotopic compositions of seep pore waters because the vast majority of calcite was formed in nonseep conditions when the foraminifer was alive. Thus, for these specimens, there would be minimal and somewhat predictable isotopic disequilibrium [McCorkle et al., 2008] or an offset related to the magnitude of overgrowths because the specimens never lived in seeps. This explanation, however, does not account for the consistent and distinct vertical distribution patterns of Rose Bengal-stained foraminifera within sediments of these clam beds and other seeps [e.g., Rathburn et al., 2003], implying that at least some foraminiferal species survive in seeps. Our ultrastructural observations support the assertion that at least some foraminifera inhabit seeps, as does a previous ultrastructural study [Bernhard et al., 2001].

[27] Foraminifera that are able to survive seep conditions likely have bacterial associates (endobionts and/or ectobionts) and/or have anaerobic metabolic pathways. Two seep-tolerant species noted in this study are Buliminella tenuata, which can also harbor endobionts when inhabiting sulfidic sediments [Bernhard et al., 2000], and Globobulimina pacifica, which probably performs complete denitrification given results of congeners [Risgaard-Petersen et al., 2006]. As noted, no endemic seep foraminifera have been identified to date, an observation commensurate with the idea that seeptolerant specimens were born and initially calcify while exposed to nonseep conditions.

[28] It is unclear, however, how much, if any, of survivors' carbonate is precipitated during exposure to seep conditions. The isotopic composition of new chambers, formed during exposure to seep activity, may be in equilibrium with seep pore waters, yet the isotopic composition measured for the entire foraminiferal test would be in disequilibrium to seep pore waters because the mass of nonseep calcite exceeds that of seep calcite. For example, if one final chamber composing $10 \%-20 \%$ of a test's mass (e.g., as roughly occurs in Buliminella tenuata, B. mexicana, C. wuellerstorfi, U. peregrina) was precipitated during exposure to seep conditions where pore water $\delta^{13} \mathrm{C}$ was measured at $-30 \%$, then isotopic analysis of the whole test would indicate a $\delta^{13} \mathrm{C}_{\text {test }}$ value of $\sim-2 \%$ to $-5 \%$ (Figure 4 ), which roughly coincides with our isotopic results (e.g., the lowest values for bonafide live seep specimens of $B$. tenuata ranged from $\sim-2.1 \%$ to $-3.2 \%$ ). For species with significantly larger final chambers (i.e., G. pacifica, Chilostomella ovoidea in our study), up to $30 \%-40 \%$ of the carbonate mass could be precipitated in the final chamber. Again, with the addition of a chamber in pore water with $\delta^{13} \mathrm{C}_{\text {DIC }}$ of $-30 \%$, a $\delta^{13} \mathrm{C}_{\text {test }}$ value of $\sim-9 \%$ to $-11 \%$ is estimated (Figure 4), which is similar to our lightest value of $-8.5 \%$ for G. pacifica. Further, if activity of clam feet causes mixing of pore water and bottom water across the sediment water interface, then small volumes of the pore water would have isotopic compositions heavier than have been measured for the bulk seep $\delta^{13} \mathrm{C}_{\mathrm{DIC}}$ compositions. Such heterogeneity in pore water composition could also result in heavier test signatures compared to measured seep pore waters.

[29] Although data on the $\delta^{13} \mathrm{C}$ of pore waters bathing the foraminifera analyzed in this study are unavailable, the isotopically light $\delta^{13} \mathrm{C}_{\mathrm{DIC}}$ values of pore water in the Monterey Bay seeps did not change markedly between collections in 1994 and 2000 [Martin et al., 1997, 2004]. 


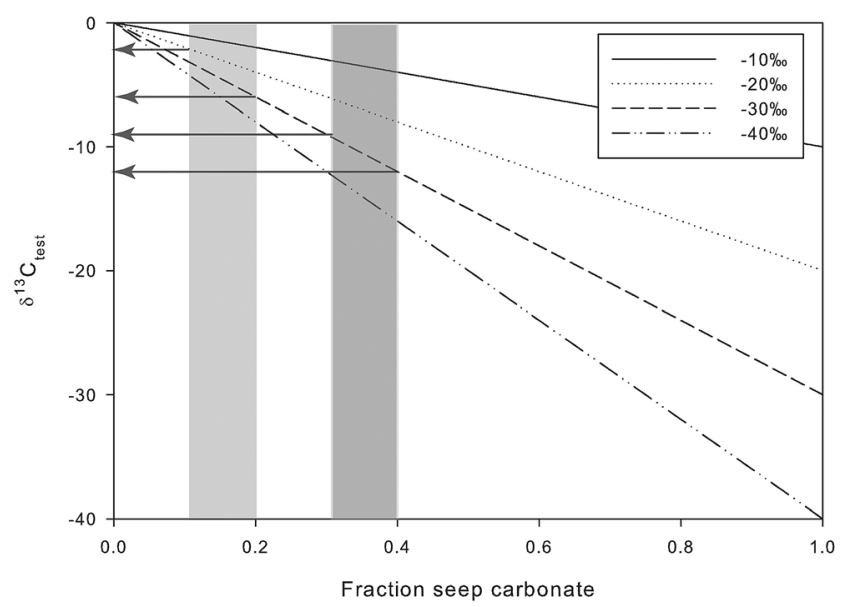

Figure 4. Mixing lines of hypothetical foraminiferal tests that were partially precipitated in seep pore waters. Specimens were assumed to precipitate carbonate in equilibrium with (1) seawater with a $\delta^{13} \mathrm{C}_{\text {DIC }}$ value of $0 \%$ (i.e., while living in a nonseep habitat) and (2) a proportion ( $x$ axis) in equilibrium with seep $\delta^{13} \mathrm{C}_{\text {DIC }}$ of varied values $(-10 \%$ (solid line), $-20 \%$ (dotted line), $-30 \%$ (dashed line), $-40 \%$ (dotted-dashed line)). This range is included to represent the possibility of heterogeneity due to upper sediment column mixing due to, e.g., seep clam activities. The light gray area shows expected $\delta^{13} \mathrm{C}_{\text {DIC }}$ value foraminifera (e.g., B. tenuata or C. wuellerstorfi) that precipitated $10 \%-20 \%$ of its test mass in $\delta^{13} \mathrm{C}_{\mathrm{DIC}}$ of $-20 \%$ to $-30 \%$. Dark gray area and arrows show expected $\delta^{13} \mathrm{C}_{\text {test }}$ value of foraminifera (e.g., G. pacifica) that precipitated $30 \%-40 \%$ of its test mass in $\delta^{13} \mathrm{C}_{\mathrm{DIC}}$ of $-30 \%$.

Our data from past collections in Clam Flats indicate that the upper few centimeters of seep pore water $\delta^{13} \mathrm{C}$ (from under clams) has a mean of $-16.2 \%$ (range of -3.2 to $-36.5 \%$, $\mathrm{n}=4,0-3 \mathrm{~cm}$ [Martin et al., 1997, 2004]), so the above calculations are generally valid. The standard technique for collection of pore water for $\delta^{13} \mathrm{C}_{\mathrm{DIC}}$ analysis involves sectioning cores (typically of $8-10 \mathrm{~cm}$ diameter) at $1-3 \mathrm{~cm}$ thick intervals and separating the water from the sediments by centrifugation or compression through a filter. This process thus extracts water from about 100 to $150 \mathrm{~cm}^{3}$ of sediment and would obliterate any microscale habitat variability relevant to foraminifera, which are typically $<1 \mathrm{~mm}$ in length. The standard extraction for pore water analyses is based on the assumption that horizontal variability of pore water composition is orders of magnitude smaller than vertical variability [Berner, 1980]. There is no a priori reason to think that seeps are laterally homogeneous. Certainly, steep horizontal gradients exist both across the seep-nonseep transition and within seeps on smaller scales [Martin et al., 1997]. Novel methods will be required to sample pore waters at scales appropriate to foraminifera; such assessments will be critical in determining in situ pore water conditions that bathe foraminifera. Analysis of additional seep habitats, such as microbial mats, would also provide a valuable comparison where, presumably, less heterogeneity exists on the microscale. Unfortunately, no micro- bial mats were found at Clam Flats at the time of our collections.

[30] If certain foraminifera are only surviving and not growing or reproducing in seep habitats, questions are raised about foraminiferal longevity without growth or reproduction, postmortem longevity of stainable foraminiferal cytoplasm, and the maintenance of vertical distribution patterns, as well as about the heterogeneity of $\delta^{13} \mathrm{C}$ distributions in pore water on a microscale. The answers to these questions will have an impact on fossil record interpretations. If foraminifera calcify small portions of their tests in seeps, an explanation has been found for the disequilibrium observed in previous seep studies [Hill et al., 2003, 2004a; Martin et al., 2004; Rathburn et al., 2003], although our next step is to determine in situ calcification rates. Also, our data could be used, perhaps, to infer ecology and physiological capabilities of species in fossil deposits. More specifically, live foraminiferal conspecifics with larger offsets in $\delta^{13} \mathrm{C}_{\text {test }}$ between seep and nonseep populations suggests more calcification occurs at seeps (e.g., G. pacifica) than those species with smaller offsets (e.g., U. peregrina, C. wuellerstorfi). Observations on the range of $\delta^{13} \mathrm{C}_{\text {test }}$ values of fossil foraminiferal conspecifics might thus be a better proxy for paleoenvironments than absolute values of the $\delta^{13} C_{\text {test }}$ of individuals from any given species [e.g., Rathburn et al., 2003].

\section{Conclusions}

[31] We show for the first time that some foraminiferal seep inhabitants have endobionts and that a positive staining reaction with Rose Bengal could indicate presence of bacterial, not foraminiferal, cytoplasm. Further, our paired cellular ultrastructure and test carbon isotope data are commensurate with the idea that most Rose Bengal-stained foraminifera collected from seeps calcify little, if any, in seep habitats and that many are dead. Our data do not fully explain the cause of isotopic disequilibrium in benthic foraminiferal carbonate; the role of diet and symbionts remain equivocal. Although multiple possible explanations exist for the cause of disequilibrium between foraminiferal carbonate and seep $\delta^{13} \mathrm{C}_{\mathrm{DIC}}$, our multidisciplinary results from individual foraminifers reconfirm that observable differences occur between seep and nonseep foraminiferal $\delta^{13} \mathrm{C}_{\text {test }}$ values: isotopically lighter carbonate and a wider range in carbon isotope values generally occur in seep foraminifera compared to nonseep foraminifera. We show here that these isotopic signals occur in foraminifera that were unequivocally live at the time of collection. Previous isotopic results relying on Rose Bengal staining could have been an artifact of misidentifying dead foraminifera, with a greater potential for authigenic overgrowths, as being live at the time of collection. We now know unequivocally that seep environments influence the isotopic signatures of at least some foraminifera living in seeps but, to date, none of the foraminifera living in seeps have carbon isotopic values that are in equilibrium with typical pore water DIC values from these seeps. These results support the idea that isotopic variability could be used in the assessment of seep paleoenvironments using fossil foraminifera. 
[32] Acknowledgments. We thank the captain and crew of the RV Atlantis, the ROV Jason support personnel, and all science party members for their assistance in sampling. We also thank Beth Richardson and Louie Kerr for their assistance and expertise in TEM sectioning and staining, Anna McIntyre-Wressnig for biostatistics advice, Jason Curtis and Kathy
Venz Curtis for help with the isotopic analyses, and two anonymous reviewers for helpful comments on an earlier version of this manuscript. This collaborative research was supported by NSF Marine Geology and Geophysics Program (OCE-0551001 (to J.M.B), OCE-0550396 (to J.B.M.) and OCE-0550401 (to A.E.R.))

\section{References}

Alexander, S. P., and F. T. Banner (1984), The functional relationsip between skeleton and cytoplasm in Haynesina germanica (Ehernberg), J. Foraminiferal Res., 14(3), 159-170, doi:10.2113/gsjfr.14.3.159.

Alve, E. (1999), Colonization of new habitats by benthic foraminifera: A review, Earth Sci. Rev., 46(1-4), 167-185, doi:10.1016/S00128252(99)00016-1.

Barry, J. P., et al. (1996), Biologic and geologic characteristics of cold seeps in Monterey Bay, California, Deep Sea Res., Part I, 43(11-12), 1739-1755, doi:10.1016/S0967-0637(96) 00075-1.

Berner, R. A. (1980), Early Diagenesis: A Theoretical Approach, 241 pp., Princeton Univ. Press, Princeton, N. J.

Bernhard, J. M. (1988), Postmortem vital staining in benthic foraminifera; duration and importance in population and distributional studies, J. Foraminiferal Res., 18(2), 143-146, doi:10.2113/gsjfr.18.2.143.

Bernhard, J. M. (1992), Benthic foraminiferal districtuion and biomass related to pore-water oxygen content: Central California continental slope and rise, Deep Sea Res., Part A, 39(3-4), 585-605, doi:10.1016/0198-0149(92)90090-G.

Bernhard, J. M. (2003), Potential symbionts in bathyal foraminifera, Science, 299(5608), 861-861, doi:10.1126/science.1077314

Bernhard, J. M., and E. Alve (1996), Survival, ATP pool, and ultrastructural characterization of benthic foraminifera from Drammensfjord (Norway): Response to anoxia, Mar. Micropaleontol., 28(1), 5-17, doi:10.1016/0377-8398 (95)00036-4

Bernhard, J. M., and S. S. Bowser (1999), Benthic foraminifera of dysoxic sediments: Chloroplast sequestration and functional morphology, Earth Sci. Rev., 46(1-4), 149-165, doi:10.1016/ S0012-8252(99)00017-3.

Bernhard, J. M., et al. (2000), The Santa Barbara Basin is a symbiosis oasis, Nature, 403(6765), 77-80, doi:10.1038/47476.

Bernhard, J. M., et al. (2001), Monterey Bay cold-seep biota: Assemblages, abundance, and ultrastructure of living foraminifera, Deep Sea Res., Part I, 48(10), 2233-2249, doi:10.1016/S0967-0637(01)00017-6.

Bernhard, J. M., A. Habura, and S. S. Bowser (2006), An endobiont-bearing allogromiid from the Santa Barbara Basin: Implications for the early diversification of foraminifera, J. Geophys. Res., 111, G03002, doi:10.1029/ 2005JG000158.

Bernhard, J. M., S. T. Goldstein, and S. S. Bowser (2010), An ectobiont-bearing foraminiferan, Bolivina pacifica, that inhabits microxic pore waters: Cell-biological and paleoceanographic insights, Environ. Microbiol., 12, 2107-2119, doi:10.1111/j.1462-2920.2009.02073.x.

Cedhagen, T. (1991), Retention of chloroplasts and bathymetric distribution in the sublittoral foraminiferan Noninellina labradorica, Ophelia, 33(1), 17-30.

Corliss, B. H. (1991), Morphology and microhabitat preferences of benthic foraminifera from the northwest Atlantic Ocean, Mar. Mi- cropaleontol., 17(3-4), 195-236, doi:10.1016/ 0377-8398(91)90014-W.

Corliss, B. H., and S. Emerson (1990), Distribution of Rose Bengal stained deep-sea foraminifera from the Nova Scotian continental margin and Gulf of Maine, Deep Sea Res., Part A, 37(3), 381-400, doi:10.1016/0198$0149(90) 90015-\mathrm{N}$

Erez, J. (1978), Vital effect on stable isotope compostiion seen in foraminifera and cora skeletons, Nature, 273(5659), 199-202, doi:10.1038/273199a0.

Goldstein, S. T., and B. H. Corliss (1994), Deposit feeding in selected deep-sea and shallow-water benthic foraminifera, Deep Sea Res., Part I, 41(2), 229-241, doi:10.1016/ 0967-0637(94)90001-9.

Gooday, A. J. (2003), Benthic foraminifera (Protista) as tools in deep-water palaeoceanography: Environmental influences on fauna characteristics, Adv. Mar. Biol., 46, 1-90, doi:10.1016/S0065-2881(03)46002-1.

Grimm, G. W., et al. (2007), Diversity of rDNA in Chilostomella: Molecular differentiation patterns and putative hermit types, Mar. Mi cropaleontol., 62(2), 75-90, doi:10.1016/j. marmicro.2006.07.005.

Grzymski, J., et al. (2002), The function of plastids in the deep-sea benthic foraminifer, Nonionella stella, Limnol. Oceanogr., 47(6), 1569-1580, doi:10.4319/lo.2002.47.6.1569.

Hanaichi, T., et al. (1986), A stable lead by modification of Sato's method, J. Electron Microsc. (Tokyo), 35(3), 304-306.

Heeger, T. (1990), Electronenmikroskopische Untersuchungen zur Ernähungsbiologie benethischer Foraminiferen, Berichte aus dem Sonderforschungsbereich, 313, 1-139.

Hill, T. M., et al. (2003), Foraminifera as indicators of methane-rich environments: A study of modern methane seeps in Santa Barbara Channel, California, Mar. Micropaleontol., 49(1-2), 123-138, doi:10.1016/S0377-8398(03)00032-X

Hill, T. M., et al. (2004a), Isotopic evidence for the incorporation of methane-derived carbon into living foraminifera from modern methane seeps, Hydrate Ridge, northeast Pacific, Geochim. Cosmochim. Acta, 68(22), 4619-4627, doi:10.1016/j.gca.2004.07.012

Hill, T. M., et al. (2004b), High-resolution records of methane hydrate dissociation: ODP Site 893, Santa Barbara Basin, Earth Planet. Sci. Lett., 223(1-2), 127-140, doi:10.1016/j. eps1.2004.04.003.

Hornbach, M. J., et al. (2007), Triggering mechanism and tsunamogenic potential of the Cape Fear Slide complex, U.S. Atlantic margin, Geochem. Geophys. Geosyst., 8, Q12008, doi:10.1029/2007GC001722.

Kennett, J. P. (2003), Methane Hydrates in Quaternary Climate Change: The Clathrate Gun Hypothesis, vol. 3, 216 pp., AGU, Washington, D. C

Kitazato, H. (1995), Recolonization by deep-sea benthic foraminifera: Possible substrate preferences, Mar. Micropaleontol., 26(1-4), 65-74, doi:10.1016/0377-8398(95)00008-9.

Lee, J. J., and O. R. Anderson (1991), Symbiosis in foraminifera, in Biology of Foraminifera, edited by J. J. Lee and O. R. Anderson, pp. 157-200, Academic, London.

Lee-Thorp, J. A. (2008), On isotopes and old bones, Archaeometry, 50, 925-950 doi:10.1111/j.1475-4754.2008.00441.x.

Leifer, I., B. P. Luyendyk, J. Boles, and J. F. Clark (2006), Natural marine seepage blowout: Contribution to atmospheric methane, Global Biogeochem. Cycles, 20, GB3008, doi:10.1029/2005GB002668.

Leutenegger, S. (1984), Symbiosis in benthic foraminifera; specificity and host adapations, J. Foraminiferal Res., 14(1), 16-35, doi:10.2113/gsjfr.14.1.16.

Leutenegger, S., and H. J. Hansen (1979), Ultrastrcutural and radiotracer studies of pore function in foraminifera, Mar. Biol. Berlin, 54(1), 11-16, doi:10.1007/BF00387046.

Levin, L. A., and R. H. Michener (2002), Isotopic evidence for chemosynthesis-based nutrition of macrobenthos: The lightness of being at Pacific methane seeps, Limnol. Oceanogr., 47(5), 1336-1345, doi:10.4319/1o.2002. 47.5.1336.

Linke, P., et al. (1995), Response of deep-sea benthic foraminifer to a simulated sedimentation event, J. Foraminiferal Res., 25(1), 75-82, doi:10.2113/gsjfr.25.1.75

Lobegeier, M. K., and B. K. Sen Gupta (2008), Foraminifera of hydrocarbon seeps, Gulf of Mexico, J. Foraminiferal Res., 38(2), 93-116, doi:10.2113/gsjfr.38.2.93.

Lutze, G. F., and H. Thiel (1989), Epibenthic foraminifera from elevated microhabitats; $\mathrm{Ci}$ bicidoides wuellerstorfi and Planulina ariminensis, J. Foraminiferal Res., 19(2), 153158, doi:10.2113/gsjfr.19.2.153.

Mackensen, A., et al. (2006), Low $\delta^{13} \mathrm{C}$ in tests of live epibenthic and endobenthic foraminifera at a site of active methane seepage, Paleoceanography, 21, PA2022, doi:10.1029/ 2005PA001196.

Martin, J. B., et al. (1997), Chemical and isotopic evidence of gas-influenced flow at a transform plate boundary: Monterey Bay, California, J. Geophys. Res., 102(B11), 24,903-24,915, doi:10.1029/97JB02154.

Martin, J. B., et al. (2004), Relationships between the stable isotopic signatures of living and fossil foraminifera in Monterey Bay, California, Geochem. Geophys. Geosyst., 5 Q04004, doi:10.1029/2003GC000629.

Martin, J. B., et al. (2010), Combined carbonate carbon isotopic and cellular ultrastructura studies of individual benthic foraminifera: Method description, Paleoceanography, 25 , PA2211, doi:10.1029/2009PA001846.

McCorkle, D. C., et al. (1990), The influence of microhabitats on the carbon isotopic composition of deep-sea benthic foraminifera, Paleoceanography, 5, 161-185, doi:10.1029/ PA005i002p00161

McCorkle, D. C., et al. (1997), Vertical distributions and stable isotopic compositions of live (stained) benthic foraminifera from the North Carolina and California continental margins, Deep Sea Res., Part I, 44(6), 983-1024, doi:10.1016/S0967-0637(97)00004-6. 
McCorkle, D. C., et al. (2008), The carbon and oxygen stable isotopic composition of cultured benthic foraminifera, Geol. Soc. Spec. Publ., 303, 135-154.

Moodley, L. (1990), Squatter behavior in softshelled foraminifera, Mar. Micropaleontol., 16(1-2), 149-153, doi:10.1016/0377-8398 (90)90033-I.

Naehr, T. H., et al. (2000), Mass wasting, ephemeral fluid flow, and barite deposition on the California continental margin, Geology, 28(4), 315-318, doi:10.1130/0091-7613 (2000) $28<315$ :MWEFFA $>2.0 . \mathrm{CO} ; 2$.

Rathburn, A. E., et al. (1996), Comparisons of the ecology and stable isotopic compositions of living (stained) benthic foraminifera from the Sulu and South China seas, Deep Sea Res., Part I, 43(10), 1617-1646, doi:10.1016/ S0967-0637(96)00071-4

Rathburn, A. E., et al. (2003), Relationships between the distribution and stable isotopic composition of living benthic foraminifera and cold methane seep biogeochemistry in Monterey Bay, California, Geochem. Geophys. Geosyst., 4(12), 1106, doi:10.1029/ 2003GC000595.

Richardson, S. L., and K. Rutzler (1999), Bacterial endosymbionts in the agglutinating foraminiferan Spiculidendron corallicolum Rutzler and Richardson, 1996, Symbiosis, 26(4), 299-312.

Risgaard-Petersen, N., et al. (2006), Evidence for complete denitrification in a benthic foraminifer, Nature, 443(7107), 93-96, doi:10.1038/ nature 05070 .
Robinson, C. A., et al. (2004), Surficial hydrocarbon seep infauna from the Blake Ridge (Atlantic Ocean, $2150 \mathrm{~m}$ ) and the Gulf of Mexico (690-2240 m), Mar. Ecol. Berlin, 25(4), 313-336, doi:10.1111/j.1439-0485. 2004.00034.x

Sen Gupta, B. K., et al. (1997), Foraminiferal colonization of hydrocarbon-seep bacterial mats and underlying sediment, Gulf of Mexico slope, J. Foraminiferal Res., 27(4), 292-300, doi:10.2113/gsjfr.27.4.292.

Sen Gupta, B. K., et al. (2007), Attachment of foraminifera to vestimentiferan tubeworms at cold seeps: Refuge from seafloor hypoxia and sulfide toxicity, Mar. Micropaleontol., 62(1), 1-6, doi:10.1016/j.marmicro.2006.06.007.

Solomon, E. A., et al. (2008), Dynamic fluid flow and chemical fluxes associated with a seafloor gas hydrate deposit on the northern Gulf of Mexico slope, Earth Planet. Sci. Lett., 270(1-2), 95-105, doi:10.1016/j.eps1.2008. 03.024 .

Solomon, E. A., et al. (2009), Considerable methane fluxes to the atmosphere from hydrocarbon seeps in the Gulf of Mexico, Nat Geosci., 2(8), 561-565, doi:10.1038/ngeo574.

Spero, H. J. (1998), Life history and stable isotope geochemistry of planktonic foraminifera, Paleontol. Soc. Pap., 4, 7-36.

Stott, L. D., et al. (2002), Does the oxidation of methane leave an isotopic fingerprint in the geologic record?, Geochem. Geophys. Geosyst., 3(2), 1012, doi:10.1029/2001GC000196.

Torres, M. E., et al. (2003), Is methane venting at the seafloor recorded by $\delta^{13} \mathrm{C}$ of benthic fora- minifera shells?, Paleoceanography, 18(3) 1062, doi:10.1029/2002PA000824.

Tryon, M. D., et al. (1999), Measurements of transience and downward fluid flow near episodic methane gas vents, Hydrate Ridge, Cascadia, Geology, 27(12), 1075-1078, doi:10.1130/0091-7613(1999)027<1075: MOTADF $>2.3 . \mathrm{CO} ; 2$.

Tryon, M. D., et al. (2002), Fluid and chemical flux in and out of sediments hosting methane hydrate deposits on Hydrate Ridge, OR, II: Hydrological processes, Earth Planet. Sci. Lett., 201(3-4), 541-557, doi:10.1016/S0012$821 \mathrm{X}(02) 00732-\mathrm{X}$

Uhle, M. E., et al. (1997), Sources of carbon and nitrogen in modern planktonic foraminifera: The role of algal symbionts as determined by bulk and compound specific stable isotopic analyses, Org. Geochem., 27(3-4), 103-113, doi:10.1016/S0146-6380(97)00075-2.

J. M. Bernhard, Department of Geology and Geophysics, Woods Hole Oceanographic Institution, 266 Woods Hole Rd., MS 52 , Woods Hole, MA 02543, USA. (jbernhard@ whoi.edu)

J. B. Martin, Department of Geological Sciences, University of Florida, 241 Williamson Hall, PO Box 112120, Gainesville, FL 32611, USA.

A. E. Rathburn, Geology Program, Indiana State University, Science Bldg. 159, Terre Haute, IN 47809, USA. 